\title{
Winter climate and plant productivity predict abundances of small herbivores in central Europe
}

\author{
Emil Tkadlec ${ }^{1,2, *}$, Jiří Zbořil ${ }^{1}$, Jan Losík ${ }^{1}$, Petr Gregor $^{1}$, Lenka Lisická1 \\ ${ }^{1}$ Palacky University, Faculty of Science, Department of Ecology \& Environmental Sciences, tr. Svobody 26, 77146 Olomouc, \\ Czech Republic \\ ${ }^{2}$ Institute of Vertebrate Biology, Academy of Sciences, Studenec 122, Brno, Czech Republic
}

\begin{abstract}
We studied winter climate influences on central European small herbivores by testing the prediction that direct physical effects of winter climate should be more pronounced in herbivores living above ground/snow than in subnivean/fossorial ones. Using correlation analysis and autoregressive modeling, we found that population growth rates of European hares, representing the former class of herbivores, are more efficiently predicted by the winter NAO index than those of common voles, representing the latter class of herbivores. We demonstrate that, whereas in hares the NAO index outperformed crop yield indices, used here as a proxy for plant production variability, it was crop yield indices that more effectively predicted population change in voles. These results suggest that the relative importance of direct and indirect effects of winter climate on herbivores may be related to their body size, the major determinant of above ground/snow or subnivean/fossorial mode of life.
\end{abstract}

KEY WORDS: Climate effects · Common vole $\cdot$ European hare $\cdot$ NAO $\cdot$ Plant productivity $\cdot$ Crop yield · Central Europe

Resale or republication not permitted without written consent of the publisher

\section{INTRODUCTION}

Wintertime is a critical period in the annual cycle of many temperate and arctic herbivores. The ecological effects of winter climate variability are now well documented for many ungulates in northern Europe (Forchhammer et al. 1998, Milner et al. 1999, Post \& Stenseth 1999, Stenseth et al. 2002a) and North America (Post \& Stenseth 1998, Forchhammer et al. 2002). The negative effect of winter for large herbivores usually increases with the depth of snow cover, imposing extreme energetic costs from thermoregulation, foraging and locomotion (Ottersen et al. 2001, Hallett et al. 2004). However, much less is known about the mechanisms underlying these effects. In general, climate may affect herbivores either directly by variation in severity of winter conditions, or indirectly through a weather-driven variation in quantity and quality of plants. The first mechanism can lend higher predictive power to climatic indices, the second one to indices of plant productivity. Both causal routes have been suggested as being implicated in processes affecting the populations of large herbivores; yet, empirical evidence for indirect mechanisms remains also largely indirect (Mysterud et al. 2001).

Herbivorous mammals vary tremendously in body size. Unlike large herbivores, the small ones, such as voles or hares, have drawn comparably less attention from researchers studying climatic effects in Europe and North America (Merritt et al. 2001, Stenseth et al. 2002b; but see Lima et al. 1999, 2001, 2002 for small rodents in South America). Consequently, it remains unclear how much the effects observed in large herbivores can be generalized to include species that are smaller in size. In fact, it is not obvious at present whether small herbivores, unlike large ones, would benefit from or be disadvantaged by e.g. snowy winters. Several positive effects of snow on the survival of small subnivean rodents have been described, such as the formation of subnivean space, representing a stable environment containing food resources and excluding many predators (Evernden \& Fuller 1972, Hansson \& Henttonen 1985, McCafferty et al. 2003). 
From this perspective, 2 size classes of herbivorous mammals can be deduced which might differ in their responses in terms of sensitivity to direct physical effects of winter climate: (1) large herbivores, living on a ground surface and experiencing winter conditions above snow cover, such as ungulates or hares, and (2) small fossorial/subnivean herbivores, surviving winter usually below snow or underground, such as voles. Whereas the former are directly exposed to any weather variation, the latter may escape unfavourable weather conditions by finding a shelter beneath the snow cover or in underground burrows. Most voles build their well-insulated nests in subnivean space, including many normally fossorial voles, or underground in winters with less snow. Direct measurements confirm that snow cover acts to insulate vole habitat from large changes in air temperature (McCafferty et al. 2003) and the well-insulated nests generally provide considerable thermal benefits, thereby reducing energy expenditure (Gebczynska \& Gebczynski 1971, Stebbins 1977, Casey 1981, Redman 1999, McCafferty et al. 2003) and increasing rates of survival (Sealander 1952). Recent detailed investigations in northern voles, however, indicate that the winters with specific mild weather may be detrimental to voles because of the formation of ice which reduces the amount of subnivean space and hence the accessibility of food resources (Aars \& Ims 2002, Korslund \& Steen 2006).

Here we analyse time-series data of abundance indices for European hares and common voles in central Europe to test for the prediction that direct effects of winter climate, as measured by the winter North Atlantic Oscillation (NAO) index, should be stronger in hares living on the snow cover or ground surface than in voles living either underground or in the subnivean environment. As the relationship between local weather and different phases of the winter NAO index has not yet been clearly established for the Czech Republic, we perform correlation analysis of NAO with temperature and precipitation over winter. To highlight the relative importance of direct and indirect effects of climate on the rate of population change in both species, we compare the predictive powers of both winter climate and plant productivity by fitting autoregressive log-linear models.

\section{MATERIALS AND METHODS}

\subsection{Basic climatic facts on the Czech Republic}

The Czech Republic is a landlocked country, lying in the central part of Europe in the middle of the temperate zone of the northern hemisphere. The climate of the Czech Republic is affected by the interaction of oceanic and continental effects. Western winds prevail and intensive cyclone type activities frequently change air masses and bring rather heavy precipitation. The maritime effect is mainly felt in Bohemia, situated in the west of the country. Continental climate effects have a bigger impact on Moravia and Silesia, situated in the east. Altitude and relief influence the climate to a large extent. About $67 \%$ of the country's whole territory can be found at an altitude below $500 \mathrm{~m}, 32 \%$ between 500 and $1000 \mathrm{~m}$, and only $1 \%$ above $1000 \mathrm{~m}$. The average altitude of the Czech Republic is $430 \mathrm{~m}$. The coldest winter month is January with mean temperatures ranging from about $-2^{\circ} \mathrm{C}$ in lowlands to $-6^{\circ} \mathrm{C}$ in mountains. The length of a period with snow cover ranges from $40-50 \mathrm{~d}$ in lowlands to 5-6 mo in mountains. The number of days with the depth of snow cover $>10 \mathrm{~cm}$ is small in most lowland areas, ranging from 5 to $45 \mathrm{~d}$ (Voženílek et al. 2006). Both hare and vole populations are more numerous in lowlands.

\subsection{Time-series data}

The European hare Lepus europaeus is among the traditional game animals of the Czech Republic. As elsewhere in Europe, population numbers of hares have started to decline severely since the late 1970s, with numbers remaining low up to the present and with no indication of recovery (Fig. 1a). We examined 11 time-series of bags (i.e. annual catch) from central and eastern Moravia: (1) 9 time-series for bags from lowland areas around Olomouc, each of 39 yr duration and covering the period 1964-2002, (2) 1 time-series of $35 \mathrm{yr}$ duration for lowland areas around Prostějov, covering the period 1966-1999, and (3) 1 time-series from upland areas around Vsetin of $39 \mathrm{yr}$ duration and covering the period 1964-2002.

The common vole Microtus arvalis is the most abundant vole species in central Europe. It preferentially inhabits open lowland grassy habitats in both farmland and natural areas. We analysed 71 time-series of vole abundance indices covering the whole territory of the Czech Republic between 1968 and 1988 (21 yr). Vole index was based on the mean number of reopened burrow entrances per district (an administrative region unit of about $1000 \mathrm{~km}^{2}$ ), collected each autumn using a standardised procedure (EPPO 1975). Data was collected from an alfalfa field as follows: five $10 \times 10 \mathrm{~m}$ squares were chosen at random and all burrow entrances found were trampled out by foot. On the next day, the counts of re-opened burrow entrances were recorded and converted to the number ha ${ }^{-1}$. These data were then categorized into 4 density categories, and published as maps for all districts of the 

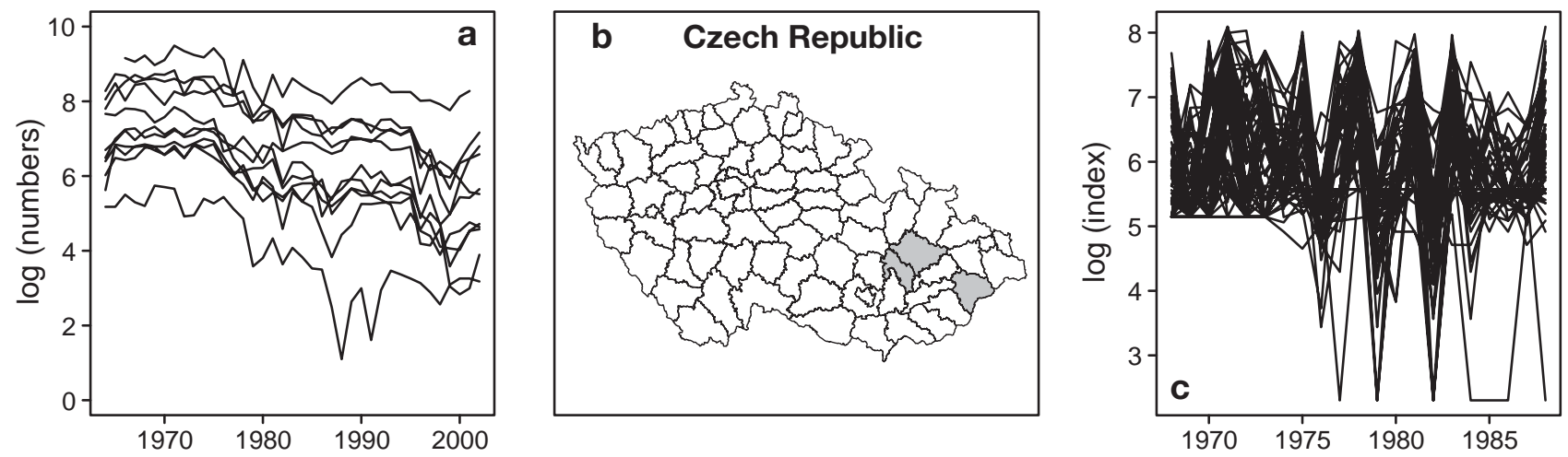

Fig. 1. (a) Population dynamics of European hare in the Czech Republic as captured by annual bags (the number of individuals shot) for 3 Moravian districts between 1964 and 2002. (b) Districts in the Czech Republic with data on hares (grey): Olomouc (9 time-series), Prostějov (1) and Vsetín (1). (c) Population dynamics of the common vole in 71 districts between 1968 and 1988 as measured by the population index based on the number of re-opened burrow entrances $\mathrm{ha}^{-1}$. The index was reconstructed from annual maps with 4 density categories of vole occurrence and calibrated using 12 original data sets. In a period 1968-1973, the lowest density category was defined to cover counts from 0 to 500 re-opened holes ha ${ }^{-1}$ (not as zero numbers as in remaining years). As a result, the density close to zero value could not be recovered within the first $6 \mathrm{yr}$, the attainable minimum being

172 holes (the geometric mean for the category 0-500 obtained from 12 original time-series data)

Czech Republic by the State Phytosanitary Administration Institute. As the original data sets on which the maps are based are no longer available, we derived our index from these maps of vole densities (Fig. 1b). We had 12 original time-series from the Czech Republic (Tkadlec \& Stenseth 2001) providing information on frequency distribution of counts within each of the density categories. We used a geometric mean to estimate the expected value within each density category. We then replaced the ordinal categories by these means and computed the arithmetic mean for each district. We had 5-10 categorical observations for each district and year. By this procedure, we recovered about $75 \%$ of the variation in the original index, with the mean correlation coefficients measuring the similarity of original and reconstructed time-series being $0.95(\mathrm{n}=12, \min =0.85, \max =0.99)$.

We used a station-based winter (Dec-Mar) NAO normalised index (www.cgd.ucar.edu/cas/jhurrell/index. html) as a proxy for climatic influences (Stenseth et al. 2003, Hallett et al. 2004, Stenseth \& Mysterud 2005). Local data on mean monthly temperature and precipitation for 7 meteorological stations were obtained from Statistical Yearbooks published annually by the Czech (formerly Czechoslovak) Statistical Office and then averaged (temperature) or summed (precipitation) over the same season as the NAO index. Stns Olomouc and Znojmo are located in lowlands of the eastern Czech Republic (called Moravia) covering the region from which data on hare population dynamics were obtained. As there are no long-term ecological estimates of annual plant production that are suitable for statistical analysis it is difficult to measure the temporal variation of plant productivity. Consequently, we used, as operational variables, annual yields for 7 main crops, including cereals, winter wheat, barley, forage crops (hay) on arable land (mainly alfalfa and clover), legumes (pea and bean), maize and rape, published regularly in Statistical Yearbooks.

\subsection{Statistical analysis}

We used 2 methodological approaches to investigate relationships between climatic, plant productivity and abundance indices. First, correlation analysis was used to examine the association between the 2 time-series data sets. This approach was applied to the following pairs of variables: (1) winter NAO index $\left(\mathrm{NAO}_{t}\right)$ with local temperature or rainfall, (2) winter NAO index with herbivore abundances, (3) winter NAO index with crop yield indices $\left(P_{t}\right)$, and (4) crop indices with herbivore abundances. All time-series were differenced to make them stationary before we computed Pearson correlation coefficients. For statistical test of significance, we employed a randomization procedure (1000 replications) by holding 1 time-series constant while permuting the other series against it (Good 2005). Because of random pairing, the expected value of the correlation for simulated data is 0 . We considered the observed coefficient significantly different from zero if it fell outside the $95 \%$ confidence interval constructed for randomly resampled data and adjusted by the Bonferroni method with respect to the total number of correlated pairs in the group ( 7 for meteorological stations and 7 for crop yield indices). 
The second approach was autoregressive modeling, allowing us to analyse relationships in more than 2 data sets simultaneously. The climatic and plant productivity effects on herbivore abundance indices $N$ were examined using the basic population model:

$N_{t}=N_{t-1} \exp \left[f\left(X_{t-1}, X_{t-2}, \mathrm{NAO}_{t}, \mathrm{NAO}_{t-1}, P_{t}, P_{t-1}\right)\right]$

which assumes direct (first-order) and delayed density dependence (second-order negative feedbacks), as well as assuming a linear relationship between realized per capita population growth rates $\left(r_{t}=\ln N_{t}-\ln \right.$ $N_{t-1}$ ) and logs of population indices $X$ (the Gompertz function) (Fig. 2). The model includes current (direct, $t$ ) and delayed (indirect, $t-1$ ) climatic and plant effects as external drivers. This population model leads readily to statistical autoregressive log-linear models of the general form

$$
X_{t}=b_{0}+\sum_{i=1}^{i=2} b_{i} X_{t-i}+\sum_{j=0}^{j=1} c_{j} \mathrm{NAO}_{t-j}+\sum_{k=0}^{k=1} d_{k} P_{t-k}+\varepsilon_{t}
$$

where the autoregressive process can be of the order 0,1 or 2 , and $\varepsilon_{t}$ represents normally distributed random variable with zero mean and constant variance (noise). The autoregressive coefficients for $X$
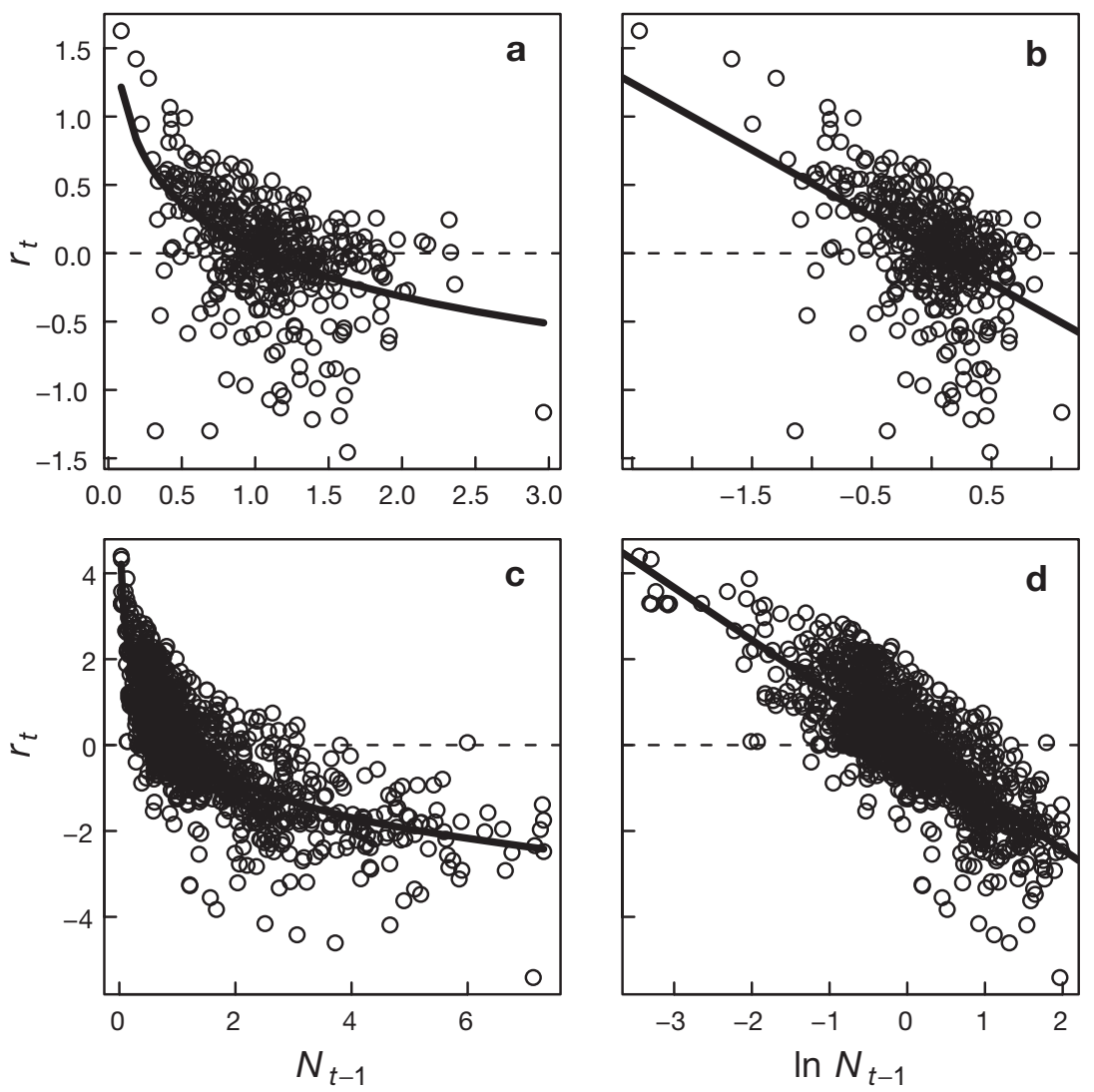

Fig. 2. Concave direct density dependence in (a) hares and (c) voles. Log-transforming herbivore abundance indices resulted in roughly linear relationships in both (b) hares and (d) voles, thus meeting the assumption of auto-regressive linear models are denoted as $b$, the regression coefficients for NAO

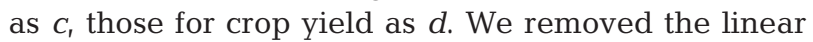
trend from all variables. The best model structure (order of the autoregressive process + any combination of direct and indirect climate and plant effects) was found empirically by fitting all possible models to all time-series available for that species and picking up the model with the lowest $\Sigma \mathrm{AICC}_{m}$, where AICC is a corrected Akaike information criterion for small sample size (Hurvich \& Tsai 1989) obtained as $\mathrm{AIC}+2 K(K+1) /(n-K-1)$ for each of the timeseries $m=1, \ldots, 11$ for hares and $m=1, \ldots, 71$ for voles. $K$ is the number of estimable parameters (e.g. $K=2$ for pure zero-order model) and $n$ is the length of the time-series. This criterion measures the global performance of the given model structure for all time-series data sets. It is a common practice in analyses of time-series to consider the difference between 2 AICc values $\geq 1$ as significant (e.g. Tkadlec \& Stenseth 2001). We extended this approach when assessing the significance of differences in $\Sigma \mathrm{AICC}_{m}$ between various model structures. We took for significant those differences in $\Sigma \mathrm{AICC}_{m}$ values that were greater than $n$.

The final relationship between the realized per capita population growth rate $r$ and external driver (NAO, crop yield indices) that follows from the best model structure was modeled by fitting generalized additive models (GAM) using 4 degrees of freedom for cubic smoothing splines as described in Hastie \& Tibshirani (1990). All statistical analyses were done using functions implemented in $\mathrm{R}$ software ( $\mathrm{R}$ Development Core Team 2005).

\section{RESULTS}

\subsection{Correlation analysis}

Annual changes in the winter NAO index are significantly correlated with the corresponding changes in mean winter temperature throughout the Czech Republic, with correlation coefficients ranging from 0.43 to 0.61 (Table 1). However, this is not the case with total winter precipitation, which clearly varies spatially and the association may be positive or negative. These results suggest that the positive phase of NAO is associated with warmer winters but the precipitation pattern is sitespecific, depending on local conditions. 
Table 1. Pearson correlation coefficients measuring the association between the winter NAO index and each of local winter temperature and local winter precipitation from 1963 to 2002. Because of missing weather data for 1979, we omitted values for 1979 and 1980 from the analysis. Correlations were computed with differenced variables and statistical significance assessed by randomization $\left(1000\right.$ replicates). ${ }^{*}$ Coefficient differs from $0(\mathrm{p}<0.007)$

\begin{tabular}{|c|c|c|c|c|c|}
\hline \multirow{2}{*}{$\begin{array}{l}\text { Meteorological } \\
\text { station }\end{array}$} & \multirow{2}{*}{$\begin{array}{l}\text { Elevation } \\
\quad(\mathrm{m})\end{array}$} & \multirow{2}{*}{ Latitude } & \multirow{2}{*}{ Longitude } & \multicolumn{2}{|c|}{$\longrightarrow$ Correlation coefficient } \\
\hline & & & & Temperature & Precipitation \\
\hline České Budějovice & 388 & $48^{\circ} 58^{\prime} \mathrm{N}$ & $14^{\circ} 28^{\prime} \mathrm{E}$ & $0.435^{*}$ & -0.024 \\
\hline Hradec Králové & 278 & $50^{\circ} 11^{\prime} \mathrm{N}$ & $15^{\circ} 50^{\prime} \mathrm{E}$ & $0.483^{*}$ & $0.431^{*}$ \\
\hline Klatovy & 430 & $49^{\circ} 23^{\prime} \mathrm{N}$ & $13^{\circ} 18^{\prime} \mathrm{E}$ & $0.464^{*}$ & 0.264 \\
\hline Liberec & 398 & $50^{\circ} 46^{\prime} \mathrm{N}$ & $15^{\circ} 01^{\prime} \mathrm{E}$ & $0.538^{*}$ & $0.506^{*}$ \\
\hline Milešovka & 833 & $50^{\circ} 33^{\prime} \mathrm{N}$ & $13^{\circ} 56^{\prime} \mathrm{E}$ & $0.612^{*}$ & 0.236 \\
\hline Olomouc-Slavonín & 225 & $49^{\circ} 34^{\prime} \mathrm{N}$ & $17^{\circ} 14^{\prime} \mathrm{E}$ & $0.526^{*}$ & -0.305 \\
\hline Znojmo-Kuchařovice & 334 & $48^{\circ} 53^{\prime} \mathrm{N}$ & $16^{\circ} 5^{\prime} \mathrm{E}$ & $0.544^{*}$ & -0.278 \\
\hline
\end{tabular}

Correlation coefficients measuring the association of per capita growth rates in hares and yearly changes in the winter NAO index were all positive, 7 out of 11 (>0.35) being significantly different from zero (Fig. 3a). In voles, they were also mostly positive, with 29 out of 71 (>0.38) being significantly different from 0 (Fig. 3b). Hence, abundances of both herbivore species tend to respond positively to the increased NAO index, which corresponds to warmer winters in the Czech Republic.

There was no direct relationship (lag 0 ) between annual changes in the winter NAO index and corresponding changes in 7 crop-yield indices (Table 2). The only pattern observed, though weak, was that found at Lag 2 where all coefficients were positive and at Lag 3 where all coefficients were negative, especially for cereals.

Annual changes in crop yield indices were weakly associated with per capita population growth rates in herbivores, especially in hares (Table 3). However, all correlations for Lag 2 were negative in both herbivores.

\subsection{Autoregressive modeling}

We obtained 4 major results when modeling timeseries of hare abundances (Fig. 4a):

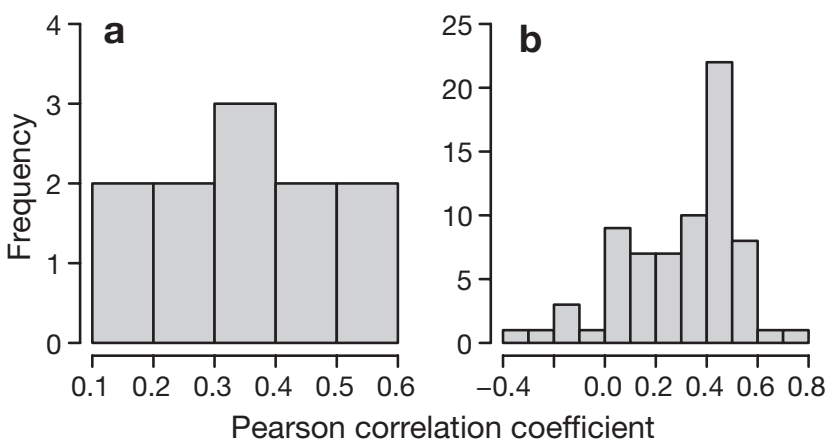

Fig. 3. Distribution of Pearson correlation coefficients $(r)$ for the association between annual changes in the winter NAO index and per capita population growth rates in (a) hares and (b) voles
- the best autoregressive model structure was of order $1[\operatorname{ar}(1)]$, and included the direct NAO effect $\left(\mathrm{NAO}_{t}\right)_{i}$

- the best model fit was significantly better than those of pure autoregressive models yielding the differences in $\Sigma \mathrm{AICc}_{m}$ of 29.9 and 51.8 for $\operatorname{ar}(1)$ and $\operatorname{ar}(2)$, respectively;

- the best model outperformed significantly all other models, except that at the second place that contained maize as additional predictor;

- all models except 2 among the first 20 models contained the direct effects of NAO $\left(\mathrm{NAO}_{t}\right)$. The results suggest that more hares are shot after mild winters with an increased NAO index (Fig. 5a,b) and that winter climate is better than plant production indices for predicting hare abundances in autumn.

Modeling vole data revealed a different pattern (Fig. 4b):

- the best model structure was of order $0[\operatorname{ar}(0)]$ and included the direct effect of legumes;

- the best model fitted the data significantly better than the pure autoregressive models, the drops in $\Sigma \mathrm{AICC}_{m}$ against $\operatorname{ar}(0)$ and $\operatorname{ar}(1)$ of 75.6 and 163.0, respectively;

- the pure autoregressive model [ar(0)] outperformed the most successful model with NAO effects $[\operatorname{ar}(0)+$ $\mathrm{NAO}(t-1)]$, the difference in $\Sigma \mathrm{AICc}_{m}$ being 75.6;

Table 2. Pearson cross-correlation coefficients measuring the association between the winter NAO index and yield indices for 7 crops with lags of 0 to $3 \mathrm{yr}$ in the period 1963-2002. All variables were differenced $(n=39) .{ }^{*} p<0.007$

\begin{tabular}{|c|c|c|c|c|}
\hline \multirow{2}{*}{ Crop } & \multicolumn{4}{|c|}{ Jâr } \\
\hline & 0 & 1 & 2 & 3 \\
\hline Cereals & -0.106 & 0.250 & 0.130 & $-0.388^{*}$ \\
\hline Wheat & -0.072 & 0.112 & 0.236 & $-0.423^{*}$ \\
\hline Barley & -0.116 & 0.256 & 0.091 & $-0.325^{*}$ \\
\hline Legumes & 0.119 & -0.055 & 0.102 & -0.190 \\
\hline Forage crops & -0.312 & 0.068 & 0.132 & -0.150 \\
\hline Maize & -0.304 & -0.123 & 0.146 & -0.208 \\
\hline Rape & 0.230 & -0.048 & 0.069 & -0.131 \\
\hline Mean & -0.080 & 0.066 & 0.129 & -0.259 \\
\hline
\end{tabular}



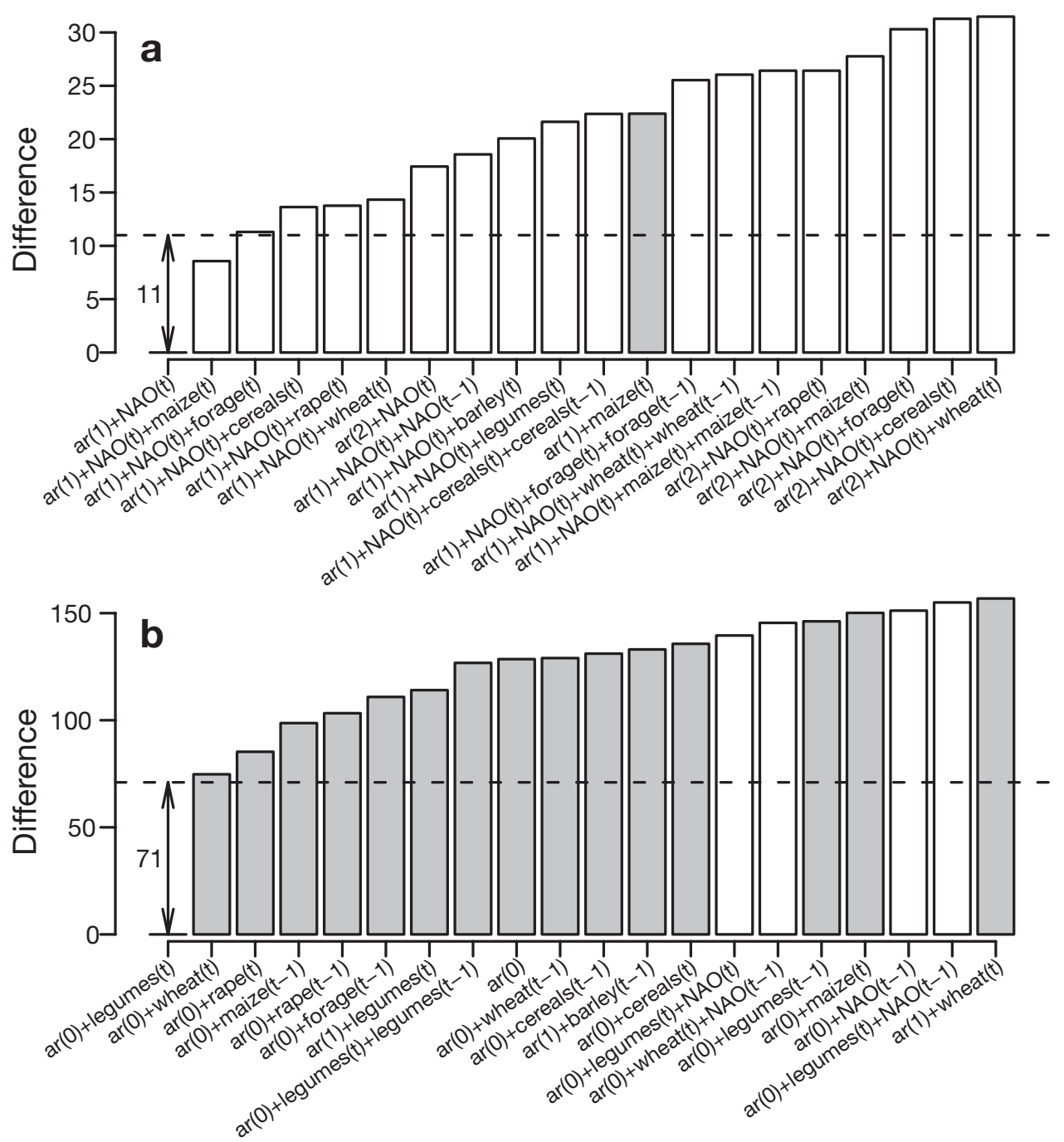

Fig. 4. Selection of the best model structure in (a) hares and (b) voles using the difference in $\Sigma \mathrm{AICc}_{m}$ where $m=1, \ldots, n$ and $n=11$ for hares and $n=71$ for voles. Dashed line: critical value above which the differences were considered significant; white bars: model structures that contain climatic effect (any with an NAO component ), grey bars: structures with no climatic effect. ar(x): number in parentheses indicates order of autoregressive model. Only first 20 model structures shown. The best model is leftmost on the $x$-axis

- the most successful model containing NAO term did not appear earlier than at position 8 among the models of the candidate set, being clearly outperformed by models containing crop indices. These results all suggest that crop productivity indices better predict vole abundances than winter climate and vole population densities are higher in years favorable for pea and bean (Fig. 5c).

\section{DISCUSSION}

Large-scale climate indices have turned out to be very successful in predicting ecological processes in populations of large her-
Table 3. Pearson cross-correlation coefficients measuring the association between indices of herbivore abundance (log-transformed) and crop yield indices within 1968-1988. Lags 1 and 2 represent correlations between herbivore abundance in year $t$ and crop index in year $t-1$ and $t-2$. All series were differenced before computation $(\mathrm{n}=20)$. No coefficient differs from 0 ( $p<0.007)$

\begin{tabular}{|c|c|c|c|c|c|c|}
\hline \multirow{2}{*}{ Crop } & \multicolumn{3}{|c|}{$\longrightarrow$ Hares $\longrightarrow$} & \multirow[b]{2}{*}{ Lag 0} & \multirow{2}{*}{$\begin{array}{l}\text { Voles } \\
\text { Lag } 1\end{array}$} & \multirow[b]{2}{*}{ Lag 2} \\
\hline & Lag 0 & Lag 1 & Lag 2 & & & \\
\hline Cereals & 0.094 & 0.046 & -0.104 & 0.237 & 0.037 & -0.343 \\
\hline Wheat & 0.071 & 0.133 & -0.171 & 0.279 & 0.098 & -0.391 \\
\hline Barley & 0.040 & 0.053 & -0.119 & 0.066 & 0.176 & -0.411 \\
\hline Legumes & 0.071 & -0.002 & -0.046 & 0.381 & -0.117 & -0.184 \\
\hline Forage crops & -0.109 & 0.108 & -0.111 & -0.022 & 0.227 & -0.355 \\
\hline Maize & -0.273 & -0.092 & -0.053 & -0.315 & 0.289 & -0.224 \\
\hline Rape & 0.246 & -0.036 & -0.117 & 0.352 & 0.017 & -0.223 \\
\hline Mean & -0.020 & 0.030 & -0.103 & 0.140 & 0.104 & -0.304 \\
\hline
\end{tabular}



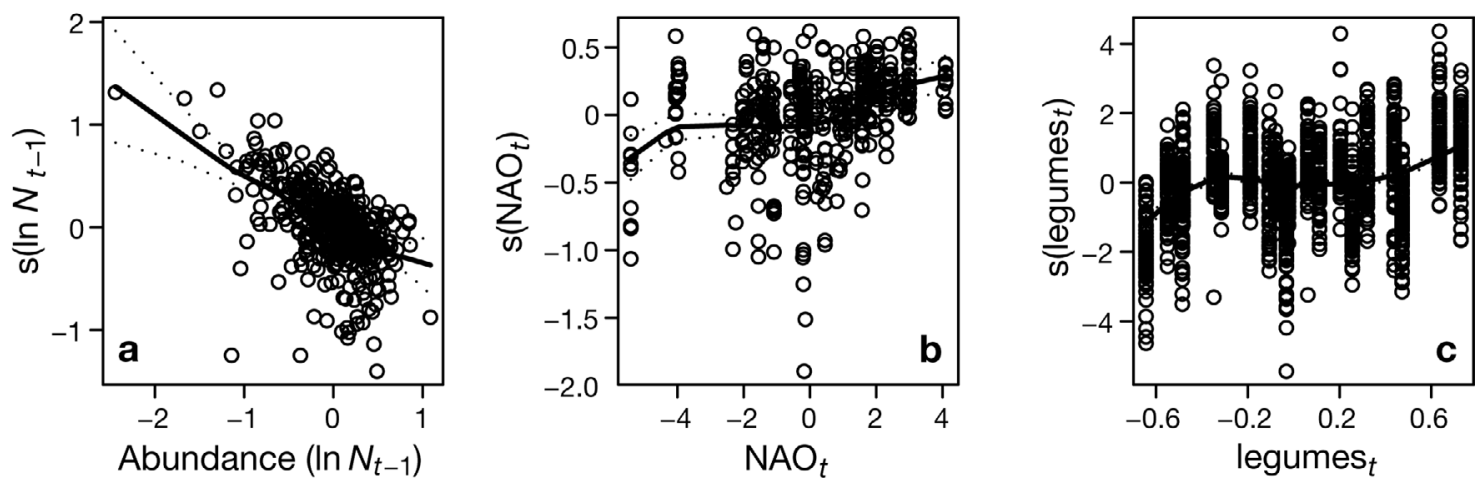

Fig. 5. The relationships between population growth rates (partial residuals) and the predictors as represented by the best model structure for $(\mathrm{a}, \mathrm{b})$ hares and (c) voles by fitting generalized additive model (GAM). The model for hares contains the direct density dependence $\left(\ln N_{t-1}\right)$ and direct climate effect $\left(\mathrm{NAO}_{t}\right)$ whereas that for voles incorporates only the effect of crop yield $\left(\right.$ legumes $\left._{t}\right)$. Some small amounts of non-linearity seem to be present in regression lines for NAO and legumes. Dotted lines: $95 \%$ confidence interval for the regression curve

bivores (Forchhammer et al. 1998, 2002, Post \& Stenseth 1998, 1999, Hallett et al. 2004). Here we present additional evidence on climate influences in central European small herbivores by testing the prediction that direct physical effects of winter climate should be more pronounced in above ground/snow living herbivores than subnivean/fossorial ones. In agreement with the prediction, population growth rates in hares, representing the former class of herbivores, are more efficiently predicted by the winter NAO index than those in common voles, representing the latter class of herbivores. Moreover, we demonstrated in voles that crop yield indices, used as operational proxies to measure variability in plant productivity, were much more efficient predictors than climatic ones, whereas in hares, it was the climate models that were more predictive. These results suggest that the relative importance of direct and indirect effects of winter climate in herbivores may be related to their body size, the major determinant of above ground/ snow or subnivean/fossorial mode of life.

As predicted by theoretical reasoning, models incorporating NAO terms performed well in hares but not in voles. This provides evidence that in a temperate zone, the direct physical influences of climate affect the herbivore living in subnivean space or underground less than the above ground/snow herbivore. This can be explained either by the insulating effect of ground/snow covers alone, protecting vole habitat from large changes in air temperature, or by interaction of climate effects with other processes, e.g. predation. Positive between-year changes in winter NAO index, associated with warmer and probably less snowy winters in Moravia, Czech Republic (see also Wibig 1999, Stenseth et al. 2002b for similar conclusions), predicted an increase in hare population densities. As we are the first to report empirical evidence on the effects of large-scale climate variability in hares, no comparison with published data can be made. The responses of hares match well the expectations that warmer temperature (perhaps with less rain and snow) represents a favorable winter condition for abovesnow herbivores (but see Stenseth \& Mysterud 2005 for more complex relationships). Although winter climate forcing cannot explain the overall decline in European hare populations throughout Europe over last 3 decades (see Hurrell 1995 for information on increasingly positive NAO index values in last decades), it is definitely a candidate for causing the short-term fluctuations in hare numbers around this downward trend. The overall effect of the NAO in voles was much weaker but the direction of response was the same as with hares. This may seem to be at odds with experimental evidence for northern voles, that snow in mild winters is transformed to form a layer of ice on a ground surface limiting severely the subnivean space beneath it (Aars \& Ims 2002). These diverging observations are not directly comparable. We need to see how much these special snow-melting conditions in winter are reflected in the variability of the NAO index, the common indicator of winter climate variability in timeseries analyses.

Variability in plant productivity represents another plausible mechanism by which climate may influence populations of herbivores (Langvatn et al. 1996, Aanes et al. 2002). At the plant level, the presence of snow cover influences physiological processes by offering protection against frost damage, dehydration and physical damage from wind and windblown particles (Walker et al. 2001). Variation in plant productivity resulting from large fluctuations in winter climate should therefore be higher in snow-free places. In the Czech Republic, these areas are situated in lowlands and are used predominantly for farming. Typically, it is the vole populations from these areas that exhibit the largest inter-annual variation in size (Tkadlec \& 
Stenseth 2001). However, we did not find any clear pattern for co-variation of NAO and crop yields. It is possible that the analysis of winter climate effects alone may not be sufficient to reveal such covariation, even though recent evidence regarding winter NAO effects on quality and quantity of winter wheat in the UK suggests there is a relationship (Kettlewell et al. 1999, Atkinson et al. 2005). Moreover, most crops are annuals sown each spring, which may interfere considerably with processes, generating delayed climatic effects (e.g. cumulative climate influences). However, by comparing the performance of climate and plant indices, our findings do suggest that the causal link between plants and herbivore may be more important to the class of small fossorial herbivores than that of large herbivores.

There is ample evidence that variations in food availability are highly related to population dynamics of small temperate and arctic rodents (Laine \& Henttonen 1983, Eurola et al. 1984, Selås 1997), especially in seed eating forest rodents (Jensen 1982, Pucek et al. 1993, Crespin et al. 2002, Stenseth et al. 2002b). Most importantly, hornbeam and oak seed crops incorporated in autoregressive models to analyse variation in annual numbers of wood mice and bank voles in the Bialowieża forest (Poland) clearly outperformed the NAO (Stenseth et al. 2002b). By incorporating annual yields for 7 crops, we obtained similar results for a herbivorous vole inhabiting open habitats, such that the population was effectively decoupled from annual variation in seed production by woody plants. If higher availability of food improves survival and stimulates vole reproduction in forests, then what represents 'seeds' in grassy habitats? Although the predictive ability of crop production indices differed highly among vole populations, edible legumes (including peas and beans) predicted their growth rates better than other types of crop. We have no clear answer for why this is so. Apart from considering the possible data-dredging effect, legumes could become superior predictors because of their high protein content. This feature of legumes leads us to hypothesize that climate conditions favorable for high annual yield of legumes are likewise favorable to high production of soluble amino acids in most plants - the easiest available source of nitrogen for herbivores (White 1993). There is evidence suggesting that besides the energetic component, proteins may be a key factor influencing diet choice in both small (Bergeron \& Jodoin 1987, Brathen et al. 2004, Bakker et al. 2005) and large herbivores (Albon \& Langvatn 1992, Langvatn \& Hanley 1993, Côte \& Festa-Bianchet 2001) by stimulating reproduction in adults and behaving as a limiting factor for rapid sexual and somatic growth in young animals (White 1993). Consequently, it would be advisable in the research of herbivorous mammals to focus more on the interface between climate and plant chemistry, especially on variation in protein metabolism in response to climate variation.

There are important caveats with this study that need to be stressed when interpreting the results: - we compared only 2 herbivore species, and so more evidence on other small and large herbivores is necessary before any firm conclusion is reached

- there was a high spatial variation in the effect of NAO on vole population growth rates, with the lowland populations tending to respond more than the populations at higher altitudes (Fig. 3b). Hence, we need to examine the geographic pattern of variation in vole responses to winters relative to the geographic pattern in winter conditions in the Czech Republic. The same holds true for responses to crop yield indices;

- the studied hare populations come from a smaller area than the vole populations. Consequently, it remains unclear what the result would be if populations from the whole territory of the Czech Republic were analysed;

- the common vole is more fossorial than other voles, such as the field vole Microtus agrestis or tundra vole Microtus oeconomus. Thus we do not know how representative these results are for other voles, even though bank voles in Bialowieża seem to show the similar relative sensitivity to climate and food (Stenseth et al. 2002b);

- climatic influences depend strongly on a specific combination of the local pattern in temperature and precipitation variability, and also on other factors (e.g. predators), thereby limiting the relevance of our findings to other regions in Europe. All these points act to restrict the general applicability of the study. It is therefore important not to overstate the observed differences until we examine other data from central Europe.

Our findings suggest that the responses of herbivore population growth rates to winter climate may not be uniform even at the same location (depending on their body size). Larger herbivores, living on the ground surface or on snow cover, and exposed directly to harsh winter conditions, are more likely to be affected directly through changes in their physiology. Small herbivores, occupying the subnivean environment or living underground in snow-free places, may be less sensitive to direct physical effects of climate and be more affected indirectly by changes in physiology of plants, especially those in protein metabolism. Further investigations along these research avenues are therefore warranted.

Acknowledgements. We thank Jan Niedoba for providing the data on hare bags in Prostějov district. The research was supported by grant GA CR No. 206/04/2003. 


\section{LITERATURE CITED}

Aanes R, Saether BE, Smith FM, Cooper EJ, Wookey PA, Øritslans NA (2002) The Arctic Oscillation predicts effects of climate change in two trophic levels in a high-arctic ecosystem. Ecol Lett 5:445-453

Aars J, Ims RA (2002) Intrinsic and climatic determinants of population demography: the winter dynamics of tundra voles. Ecology 83:3449-3456

Albon SD, Langvatn R (1992) Plant phenology and the benefits of migration in a temperate ungulate. Oikos 65: 502-513

Atkinson MD, Kettlewell PS, Hollins PD, Stephenson DB, Hardwick NV (2005) Summer climate mediates UK wheat quality response to winter North Atlantic Oscillation. Agr Forest Meteorol 130:27-37

Bakker ES, Reiffers RC, Olff H, Gleichman JM (2005) Experimental manipulation of predation risk and food quality: effect on grazing behaviour in a central-place foraging herbivore. Oecologia 146:157-167

Bergeron JM, Jodoin L (1987) Defining 'high-quality' food resources of herbivores: the case for meadow voles (Microtus pennsylvanicus). Oecologia 71:510-517

Brathen KA, Agrell J, Berteaux D, Jonsdottir IS (2004) Intraclonal variation in defence substances and palatability: a study on Carex and lemmings. Oikos 105:461-470

Casey TM (1981) Nest insulation-energy savings to brown lemmings using a winter nest. Oecologia 50:199-204

Côte SD, Festa-Bianchet M (2001) Birthdate, mass and survival in mountain goat kids: effects of maternal characteristics and forage quality. Oecologia 127:230-238

Crespin L, Verhagen R, Stenseth NC, Yoccoz NG, PrevotJulliard AC, Lebreton JD (2002) Survival in fluctuating bank vole populations: seasonal and yearly variations. Oikos 98:467-479

EPPO (European and Mediterranean Plant Protection Organisation) (1975) Guidelines for the development and biological evaluation of rodenticides. EPPO Bull 5:5-49

Eurola S, Kyllönen H, Laine K (1984) Plant production and its relation to climatic conditions and small rodent density in Kilpisjärvi region $\left(69^{\circ} 05^{\prime} \mathrm{N}, 20^{\circ} 40^{\prime} \mathrm{E}\right)$, Finnish Lapland. Spec Publ Carn Mus Nat Hist 10:121-130

Evernden LN, Fuller WA (1972) Light alteration caused by snow and its importance to subnivean rodents. Can J Zool 50:1023-1032

Forchhammer MC, Stenseth NC, Post E, Langvatn R (1998) Population dynamics of Norwegian red deer: densitydependence and climatic variation. Proc R Soc Lond B, Biol Sci 265:341-350

Forchhammer MC, Post E, Stenseth NC, Boertmann DM (2002) Long-term responses in arctic ungulate dynamics to changes in climatic and trophic processes. Popul Ecol 44: 113-120

Gebczynska Z, Gebczynski M (1971) Insulating properties of the nest and social temperature regulation in Clethrionomys glareolus (Schreber). Ann Zool Fenn 8:104-108.

Good PI (2005) Introduction to statistics through resampling methods. John Wiley \& Sons, Hoboken, NJ

Hallett TB, Coulson T, Pilkington JG, Clutton-Brock TH, Pemberton JM, Grenfell BT (2004) Why large-scale climate indices seem to predict ecological processes better than local weather. Nature 430:71-75

Hansson L, Henttonen H (1985) Gradients in density variations of small rodents: the importance of latitude and snow cover. Oecologia 67: 394-402

Hastie TJ, Tibshirani RJ (1990) Generalized additive models. Chapman \& Hall, London
Hurrell JW (1995) Decadal trends in the North Atlantic Oscillation: regional temperatures and precipitation. Science 269:676-679

Hurvich CM, Tsai CL (1989) Regression and time-series model selection in small samples. Biometrika 76:297-307

Jensen TS (1982) Seed production and outbreaks of noncyclic rodent populations in deciduous forests. Oecologia 54:184-192

Kettlewell PS, Sothern RB, Koukkari WL (1999) UK wheat quality and economic value are dependent on the North Atlantic oscillation. J Cereal Sci 29:205-209

Korslund L, Steen H (2006) Small rodent winter survival: snow conditions limit access to food resources. J Anim Ecol 75:156-166

Laine K, Henttonen H (1983) The role of plant production in microtine cycles in northern Fennoscandia. Oikos 40: 407-418

Langvatn R, Hanley TA (1993) Feeding-patch choice by red deer in relation to foraging efficiency: an experiment. Oecologia 95:164-170

Langvatn R, Albon SD, Burkey T, Clutton-Brock TH (1996) Climate, plant phenology and variation in age of first reproduction in a temperate herbivore. J Anim Ecol 65: 653-670

Lima M, Keymer JE, Jaksic FM (1999) El Niño-southern oscillation-driven rainfall variability and delayed density dependence cause rodent outbreaks in western South America: linking demography and population dynamics. Am Nat 153:476-491

Lima M, Julliard R, Stenseth NC, Jaksic FM (2001) Demographic dynamics of a neotropical small rodent (Phyllotis darwini): feedback structure, predation and climatic factors. J Anim Ecol 70:761-775

Lima M, Stenseth NC, Jaksic FM (2002) Population dynamics of a South American rodent: seasonal structure interacting with climate, density dependence and predator effects. Proc R Soc Lond B, Biol Sci 269:2579-2586

McCafferty DJ, Moncrieff JB, Taylor IR (2003) Winter microclimate of field voles Microtus agrestis in SW Scotland. J Therm Biol 28:397-401

Merritt JF, Lima M, Bozinovic F (2001) Seasonal regulation in fluctuating small mammal populations: feedback structure and climate. Oikos 94:505-514

Milner JM, Elston DA, Albon SD (1999) Estimating the contributions of population density and climatic fluctuations to interannual variation in survival of Soay sheep. J Anim Ecol 68:1235-1247

Mysterud A, Stenseth NC, Yoccoz NG, Langvatn R, Steinheim G (2001) Nonlinear effects of large-scale climatic variability on wild and domestic herbivores. Nature 410: 1096-1099.

Ottersen G, Planque B, Belgrano A, Post E, Reid PC, Stenseth NC (2001) Ecological effects of the North Atlantic Oscillation. Oecologia 128:1-14

Post E, Stenseth NC (1998) Large-scale climatic fluctuation and population dynamics of moose and white-tailed deer. J Anim Ecol 67:537-543

Post E, Stenseth NC (1999) Climatic variability, plant phenology, and northern ungulates. Ecology 80:1322-1339

Pucek Z, Jędrzejewski W, Jędrzejewska B, Pucek M (1993) Rodent population dynamics in a primeval deciduous forest (Białowieża National Park) in relation to weather, seed crop, and predation. Acta Theriol 38:199-232

R Development Core Team (2005) R: a language and environment for statistical computing. R Foundation for Statistical Computing, Vienna

Redman P, Selman C, Speakman JR (1999) Male short-tailed 
field voles (Microtus agrestis) build better insulated nests than females. J Comp Physiol B 169:581-587

Sealander JA (1952) The relationship of nest protection and huddling to survival of Peromyscus at low temperatures. Ecology 33:63-71

Selås V (1997) Cyclic population fluctuations of herbivores as an effect of cyclic seed cropping of plants: the mast depression hypothesis. Oikos 80:257-268

Stebbins LL (1977) Some aspects of overwintering in Peromyscus maniculatus. Can J Zool 56:386-390

Stenseth NC, Mysterud A (2005) Weather packages: finding the right scale and composition of climate in ecology. J Anim Ecol 74:1195-1198

Stenseth NC, Mysterud A, Ottersen G, Hurrell JW, Chan KS Lima M (2002a) Ecological effects of climate fluctuations. Science 297:1292-1296

Stenseth NC, Viljugrein H, Jędrzejewski W, Mysterud A, Pucek Z (2002b) Population dynamics of Clethrionomys glareolus and Apodemus flavicollis: seasonal components of density dependence and density independence. Acta Theriol 47:39-67

Submitted: November 13, 2005; Accepted: August 11, 2006
Stenseth NC, Ottersen G, Hurrell JW, Mysterud A, Lima M, Chan KS, Yoccoz NG, Adlandsvik B (2003) Studying climate effects on ecology through the use of climate indices: the North Atlantic Oscillation, El Niño Southern Oscillation and beyond. Proc R Soc Lond B, Biol Sci 270:2087-2096

Tkadlec E, Stenseth NC (2001) A new geographical gradient in vole population dynamics. Proc R Soc Lond B, Biol Sci 268:1547-1552

Voženílek V, Mikova T, Tolasz R, Valerianova A (2006) Climate atlas of Czechia. CHMI, Praha, (in press)

Walker DA, Billings WD, de Molenaar G (2001) Snow-Vegetation interactions in tundra environments. In: Jones HG, Pomeroy JW, Walker DA, Hoham RW (eds) Snow ecology. An interdisciplinary examination of snow-covered ecosystems. Cambridge University Press, Cambridge, p 266-324

White TCR (1993) The inadequate environment: nitrogen and the abundance of animals. Springer, Berlin

Wibig J (1999) Precipitation in Europe in relation to circulation patterns at the $500 \mathrm{hPa}$ level. Int J Clim 19:253-269

Proofs received from author(s): September 21, 2006 